\title{
Socioeconomic Analysis and Technical Efficiency among Smallholder Sorghum Farmers in Ga- Masemola Township of Limpopo Province, South Africa
}

\author{
Moswane Precious Botiabane1, L. Zhou², I.B. Oluwatayo', Fakunle Olufemi Oyedokun², \\ Akeem Adewale Oyelana ${ }^{3 *}$ \\ ${ }^{1}$ Faculty of Science and Agriculture, University of Limpopo South Africa \\ ${ }^{2}$ Risks and Vulnerability Assessment Center, University of Fort Hare, Alice, South Africa \\ ${ }^{3}$ Faculty of Commerce and Management, University of Fort Hare, Alice, South Africa \\ 201317831@ul.ac.za,Lzhou@ufh.ac.za, isaac.oluwatayo@ul.ac.za, Ofakunle@ufh.ac.za, *201100592@ufh.ac.za
}

\begin{abstract}
Sorghum farming group in South Africa is divided into the smallholder and business ranchers attributable to the distinctions in cultivar sizes, utility creation and production strategies. Sorghum is utilized primarily for sustenance and refreshments in Ga-Masemola (GM) town. Smallholder sorghum farmers in the town utilize some portion of their wage for recreation, goat and cows' compost are utilized as manures to enhance soil fruitfulness and increment sorghum yield, they rely upon precipitation water for water system and they have no entrance to expansion administrations. The study distinguish and depict the socioeconomic characteristics of smallholder sorghum farmers in Ga-Masemola town; it look at the causes of technical efficiency among smallholder sorghum ranchers in the town; and it recognize and portray difficulties confronted by smallholder sorghum farmers in the town. Essential information was gathered utilizing organized surveys and an example size of 48 smallholder sorghumfarmers in the town was chosen. Cobb Douglas model was utilized to analyse the information or data gotten. The socioeconomic characteristics of smallholder sorghumfarmers were:farming experience, age, sexual orientation, instructive level and family unit measure. The study indicates that the determinants of technical efficiency among smallholder sorghumfarmers in Ga-Masemola town that were observed to be huge are the measure of land dedicated and the amount of seeds utilized. Farmers are confronting difficulties, for example, sicknesses, low capital, pests, separation to the homestead, absence of water and atmosphere (i.e. climate) changes.The study suggested and recommended that smallholder sorghumfarmers in Ga-Masemola (GM) town require arable land to expand their production; they additionally require agricultureextension officers for training and spreading or disseminating information aboutinputs allocation. Besides, the smallholderfarmersshould be encouraged to utilize enhanced seeds varieties in order to expand their technical efficiency.
\end{abstract}

Keyword: Commercial Farmers, Ga-Masemola Village, Smallholder, Sorghum Farmer

\section{Introduction}

Sorghum farming group in South Africa can be grouped into the smallholder and business farming because of the distinctions underway, promoting and farm sizes. In 2007, the South African Sorghum Industry turned out with a research work that affirms sorghum as a basic to sustenance security for African continents in light of its qualities as a dry season safe yield among different grains and its nutritious qualities. The average yield of sorghum crop on smallholder farms is 0.8 tons for each hectare, this is the estimated value for all Southern African Development Community (SADC) nations. In Limpopo Province, sorghumfarmers grow and produced on 25,342 ha least, with Sekhukhune is by and large of 19,033 ha, Waterberg will deliver on 3,410 ha and Capricorn on 2899 ha. Limpopo Province is known to create more than 20,000 tons of sorghum (Mmbengeni and Mokoka, 2002). Sorghum crop is fundamentally delivered for home utilization in Ga-Masemola town. It is utilized as a part of making sustenance and drinks consumption. Sorghum farmers in these towns utilize some portion of their salary on generation, once in a while waste from goats and cattle's are utilized as composts to enhance soil richness and increment the yield on sorghum plantation, rainfall water is the significant hotspot for water system and expansion services are not given.Lefophane et al. (2013), ascertained that technical efficiency is basic in emerging agriculture. These farmers are obliged by financial circumstances; they are attached to utilizing restricted assets and rely upon government for help to move from small-scale to business purposes.

Problem Statement: Because of the significance appended to residential utilization of sorghum in the nourishment and drinks production in Ga-Masemola Village, to think about determinants of technical efficiency among smallholder sorghum farmers is right way since this will give a helpful data about the details 
include for ideal execution by these smallholder sorghum farmers.Smallholder sorghum farmers in the area more often than not hone subsistence farming and are confronting issues in shortage of assets and off base utilization of assets that are accessible for instance with the end goal for them to deliver, they require access to great quality sources of info. They have no entrance to augmentation administrations. Notwithstanding, even with the accessibility of augmentation officers who are in charge of spreading information to these farmers, thefarmers require information on the amount of the assets to use with the end goal for them to go on massive production of sorghum.They utilize goat and dairy cattle's compost as manure to enhance soil fertility and increment of sorghum yield and they additionally rely upon water from precipitation for water system purposes. A portion of the smallholderfarmersin the village need funding to purchase seeds, composts and so on.Since sorghum is utilized principally for nourishment and refreshment purposes in the village, if these smallholder sorghumfarmersare actually inefficient this may prompt diminished efficiency of sorghum and in the end prompt sustenance uncertainty, diminish work extent and will likewise debilitate farmers to keep producing sorghum crop. Hence, the study sought to examine the causes of technical efficiency of smallholder sorghum farmers in the study area.

\section{Objectives of the study}

- To examine the causes of specialized proficiency among smallholder sorghum farmersin GaMasemola (GM) village.

- Profile the financial attributes of smallholder sorghumfarmers in GM village.

- Assess the determinants of specialized effectiveness among smallholder sorghumfarmersin GM village.

- Identify the difficulties confronted by smallholder sorghum farmersin GM village.

\section{Research questions}

- What are the financial features of smallholder sorghumfarmersin GM village?

- What are the causes of specialized proficiency among smallholder sorghumfarmersin GM village?

- What are the difficulties confronted by smallholder sorghum farmers in GM villages?

\section{Literature Review}

Technical Efficiency and Its Determinants: Mokgalabone (2015) analysed the technicaland allocative effectiveness of small-scale maizefarmersin Tzaneen region. Cobb-Douglas models were utilized for the study. The Cobb-Douglas production functions results revealed that small-scale maizefarmersin Tzaneen district were in fact proficient "in the production of maize with the mean technical efficient value of $0.71 \%$ (Mokgalabone, 2015). The study additionally found thatfarmers were allocative inefficient with a mean allocative efficiency value of $0.39 \%$. The discoveries fromlogistic regression model revealed that the level of training, background in cultivating, access to water system, buying of hybrid seeds, access to credit and extension visits were emphatically noteworthy towards the production of maize. From the investigation, the smallholder farmers in Tzaneen municipality were in fact proficient in the production of maize".Stochastic frontier methodology was utilized to decide the technical efficiency among some chosen smallholder farmers in Kogi State (Adama, 2014). Consequences of the study uncovered that family and hired worker were generally utilized for cultivating exercises. It is additionally uncovered from the investigation that a substantial variety in the evaluated technical efficiencies ranges from 0.19 and 0.93 , with 0.64 as a mean value, signifyinga lot of opportunitiesfor increment in the technicalefficiency.It was additionally uncovered that small-scale maize farmers in Ga-Mothiba are subjected to diminishing returns to scale implying that small-scalefarmers are in fact technicallyinefficient in the production of maize. On-farm trainingpolicy to smallholder maize farmers was along these lines recommended to government. In conclusion, farmers must be trained in the detail engaged with seed and compost application and the need to make use of hybrid and thereis need for extension service delivery.

In Kenya, Njeru (2010) studied factors that impacts technical efficiencies among chosen farmers in Uasin Gishu area, and stochastic wilderness production functions was utilized as a part of the investigation. The work uncovered that the magnitude of technical efficiency differed from one farmer to the other ranging from 
$48.9 \%$ to $95.1 \%$ with a mean value of $87.2 \%$. This suggeststhatfarmers lost just about $13 \%$ of the conceivable yield to technical inefficiency aspects" (Njeru, 2010).The variables that prompted inefficiency were level of literacy, access to credit and responsibility for capital equipment. Propelled level of training which is 12 years or more or optional or more, altogether diminished inefficiency and furthermore access to credit facilities and having farm equipment. It was suggested that farmers should be instructed on the utilization of better practices, for example, the utilization of better-quality seeds and use of prescribed levels of compost i.e. fertiliser.The responsible factors such as, access to credit, nearness of dependents, and size of field for crop production, estimation of advantages and wage from domesticated animals' increment technical efficiency. While family measure, utilization of creature draft control, arrive size and area in low rain zones prompt inefficiency. Along these lines, it was concluded that sorghumfarmers are poorer with low incomeand assets.

"Lefophane et al. (2013),estimated technical efficiency in input use by credit and non-credit useremergingfarmers in Maruleng Municipality of Limpopo Province of South Africa. The study utilized CobbDouglas Production work model. Technical efficiency levels for credit users was observed to be 9.843 and for non-credit clients was observed to be 2.892 which is too wide and it infers that being proficient is connected to credit utilize and consequently, credit is" a critical instrument to build technicalefficiency levels of ranchers. The conclusion that excited from the examination was that credit can help ranchers in gaining inputs required in the creation procedure and in this manner, it is a vital tool for enhancing farmers specialized effectiveness level.A similar report was presented by Ataboh et al. (2014) "on determinants of specialized proficiency among ricefarmers in Kogi State. Stochastic Production Frontier Analysis" was utilized as a part of the investigation. It was uncovered that homestead size, seed, and compost utilized were essential components required for an expanded rice profitability. The specialized productivity of ricefarmersfluctuated because of the nearness of specialized wastefulness with "the mean proficiency estimation of 0.54 suggesting that around 46\% of rice yield is lost" because of farmer's wastefulness (Ataboh et al., 2014).The factors used such as, age, family unit size, and enhanced variety can cause an expansion in specialized effectiveness of rice farmers. The profitability of the elements could be enhanced by expanding, the homestead measure, amount of seed, fertiliser utilized and the level of labour. On the other hand, alternative wellsprings of agro-chemicals can be used byfarmers so as to have bumper production. Rice farmers can likewise utilize hybrids varieties of rice in order to build their specialized proficiency.

Mustapha and Salihu (2015) chipped away at the causes of specialized proficiency of maize and cowpea intercropping among women farmers in Gombe State. The investigation utilized unmistakable measurements and stochastic outskirts generation work demonstrates. Results from distinct measurements uncovered "that $61 \%$ of the respondents were between $40-59$ years with a normal ranch size of 1.88 hectares. While the results of stochastic frontier production function analysis showed that estimated coefficients(cultivate measure, manure, family work, enlisted work and amount of seed utilized) of the free factors in the model were sure and critical at either $1 \%$ or $5 \%$ level aside from amount of agro-chemicals utilized. The study uncovered that Size of family unit, educational level, cultivating background, access to extensions benefits and off-cultivate salary were the significant determinants of specialized productivity in the study area". The mean technical efficiency "of thefarmerswas 0.84 signifying that women farmers are moderately effective in maize/cowpea" inter-cropping (Mustapha and Salihu, 2015). It is suggested that a serious endeavours at growing the extent of maize/cowpea inter-cropping be giving a possibility base on the technical efficiencyfor the production system.Otieno et al. (2012) dealt with determinants of technicalefficiency on beef cattle rearing which steers farming and production in Kenya. The tools utilized were stochastic meta-frontier technique to estimate technicalefficiency levels in hamburger cows' production in Kenya. Subsequently, a Tobit model was utilized to evaluate factors that influenceefficiency. Results indicate that the averageefficiency level is 0.69; proposing chip away at enhancing beef production in Kenya is the privilege.

It was discovered that controlled dairy cattle rearing strategy, access to advertise contract, accessibility of an expert farm manager, off-cultivate salary, group size andfarmers' age all contribute decidedly to effectiveness. Be that as it may, cultivate size, wage, and formal training did not impact proficiency of cows' production. In rundown the scientist exhortation that for an improved productivity, considering the significance of the domesticated animals undertaking to rural livelihood and its potential part in destitution, there will be reduction in the requirement for suitable advancement strategies.Chepng'etich et al. (2015) led an investigation on factors that influence technical efficiency of sorghum production, smallholder 
sorghumfarmersin lower Eastern Kenya are the focus on respondents. Graphic insights and Tobit display were utilized as a part of the study. The result of the investigation revealed that technical efficiency was affected emphatically by formal training level of the family unit, quantities of years in sorghum farming,farmers' affiliations participation, Numbers of employed worker, production advice, and utilization of local compost. Family unit estimate affected technical efficiency. It was additionally prescribed that endeavours should concentrate on enhancing data streams on agronomic practices to expand specialized proficiency. Farmers ought to likewise be urged to shape and effectively take part in differentfarmers' affiliations, which upgrade learning and pooling of work assets, subsequently, enhancing specialized proficiency.

"Fadzim et al. (2016) evaluated determinants of technical efficiency among smallholder cocoa farmers in Malaysia. The investigation utilized the Tobit estimator connected in a two-arrange examination methodology. Results showed that factors proportion, farmers' involvement, record keeping, level of information and farmer's status were factually huge at $1 \%$ level of importance. Meanwhile, factors age, training, separation and life partner association were not measurably critical. These outcomes demonstrated thatfarmers'involvement and financial factors, for example, level of learning, record keeping and farmer's status could influence efficiency. The aftermath analysis showed that record keeping, level of information and status of farmers (either low maintenance or full-time) influences specialized proficiency. This outcome suggested that approaches that would specifically influence these distinguished factors ought to be sought after. Koirala et al. (2013) researched determinants of rice profitability and technical efficiency in the Philippines. The investigation utilized stochastic outskirts production technique in the Cobb-Douglas useful shape. The outcomes indicated that fuel, manure, lease of land, planting season, and land territory were the elements that influence both production and technicalefficiency of rice production. It was discovered that the mean specialized productivity score is 0.54 . It was additionally uncovered that land range, planting season, fuel cost, compost cost and land lease had positive huge association with the estimation of rice production in Philippines. In conclusion, fuel cost, compost cost, lease of land, time of planting, and land zone affected the two levels of profitability and technical efficiency levels of rice farmers in the Philippines".

Another study was also conducted by (Bahta et al., 2015) on "a meta-frontier analysis of determinants of technical efficiency in meat production", this research work was done in Botswana. The expository instruments utilized are stochastic meta-frontier model and a Tobit regression model to estimatetechnical efficiency and meta-technology ratio. Variables influencing efficiency of meat production in Botswana were additionally evaluated. The result is as per the following, the average technical efficiency "level was 0.496 for the entire example and $0.355,0.463$ and 0.571 for cattle beef farms who participate only in cattle, crops yield and little stock farming, respectively" (Bahta et al., 2015). Importantly, the study suggested that there is a need for suitable policies to be instituted regarding improving efficiency,taking into consideration the importance of livestock sector in poverty reduction. Especially, such policiesshould be targeted on provision of technology-related services such as controlled breeding methods.

\section{Methodology}

Study Area: This study was conducted in Ga-Masemola village, Makhuduthamaga Local Municipality (MLM) of Sekhukhune District (SD). SD workplaces are in Groblersdal and Makhuduthamaga is situated at Jane Furse. The "village is one of 146 settlements Makhuduthamaga region and is one of the poorest in Limpopo. Ga-Masemola town is arranged $65 \mathrm{~km}$ towards the eastern side of Marble Hall, $82 \mathrm{~km}$ south-west of Polokwane, which is the capital of Limpopo Province".

Research Instrument: Structured questionnaires were utilized to gather essential information from the respondents. Multi-stage and straightforward sampling strategies were utilized to test the respondents. The multi-organize examining was completed in stages, the principal arrange was the choice of the region from the SD and MLM were arbitrarily chosen, the second stage was the determination of the village in MLM and GM village was chosen and the last stage which is organize three was choosing respondents from the village.The study adopted random sampling technique to assess 48 smallholder sorghum farmers in the village. Graphic insights was utilized to depict the financial attributes, for example, age of the farmer, educational level, sexual orientation, family size and cultivating knowledge of smallholder sorghumfarmersin 
the study zone. The illustration used to represent this, is pie chart, while frequency tables and bar diagrams are also explored.

\section{Results and Discussion}

Figure 1: Farming experience of smallholder sorghum farmers

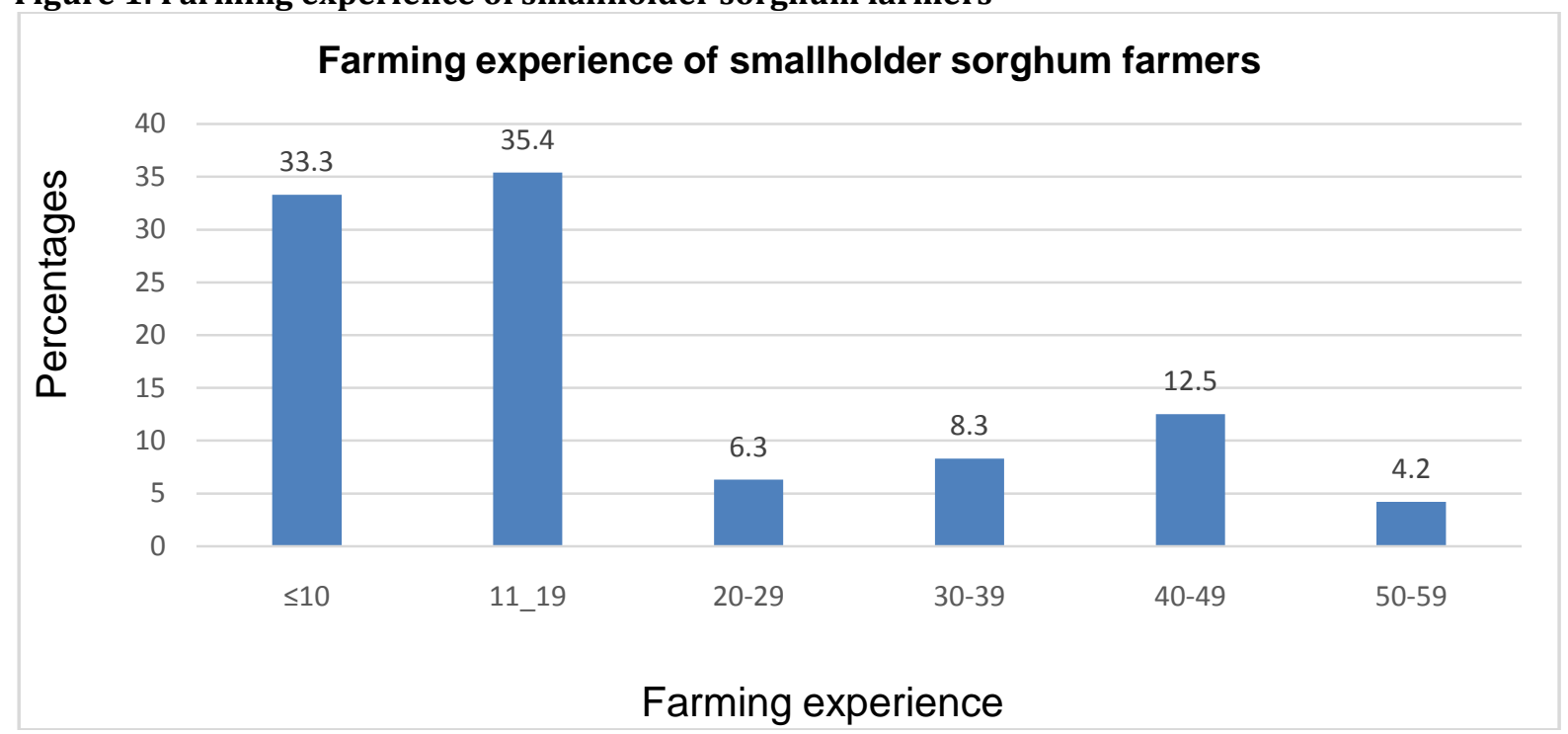

Socio-economic characteristics of smallholder sorghum farmers:Figure 1 indicates that $33.3 \%$ of farmers had been in sorghum farming for 10 years and less. 35.4\% practiced sorghum farming between 11 and 19 years. $6.3 \%$ have been in sorghum farming between 20 and 29 years. $8.3 \%$ had between 30 to 39 years of experience in sorghum farming. $12.5 \%$ of the respondents have been in sorghum farming between 40 and 49 years while $4.2 \%$ of these farmers practiced sorghum between 50 and 59 years. Most of the farmers interviewed have between 11 and 19 years of farming experience which implies that farmers are not actually familiar with the farming activities as yet and the study revealed that most of these farmers need more training in sorghum production.

Figure 2: Age of the smallholder sorghum farmers

\section{Age of the smallholder sorghum farmers}

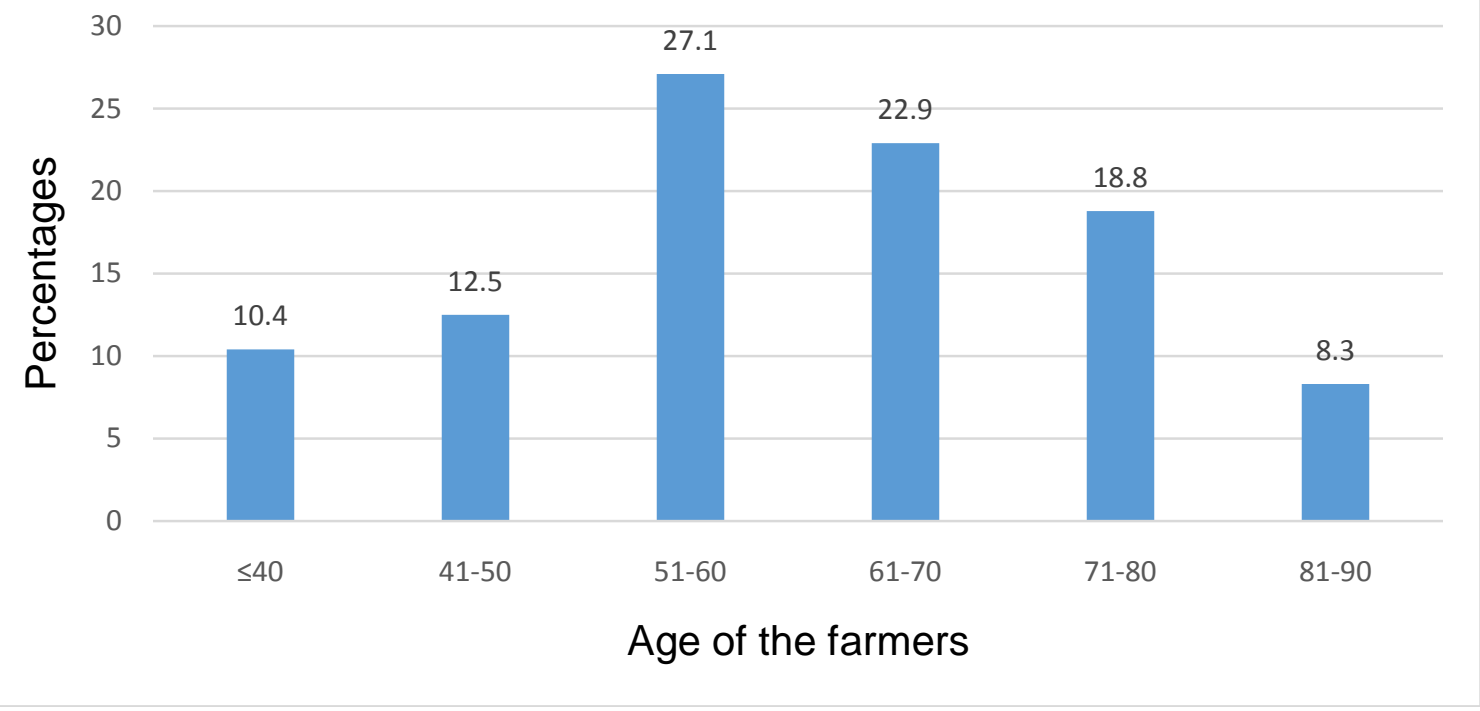


Figure 2, figure above indicates that $10.4 \%$ of the farmers interviewed were between the aged of 40 years and less. $12.5 \%$ were aged between 41 and 50 years. $27.1 \%$ were aged between 51 and 60 years. $22.9 \%$ accounted for age range between 61 and 70 years. 18.8\% were aged between 71 and 80 years while $8.3 \%$ were aged between 81 and 90 years. Majority of the active sorghum farmers were aged between 51 and 60 years. This is an indication that the area still has a lot of middle aged farmers participating in the production of sorghum. However, youth and younger aged are not into the production of sorghum in the study area, the youth should be motivated into sorghum farming.

Figure 3: Gender of the smallholder sorghum farmers

\section{Gender of farmers}

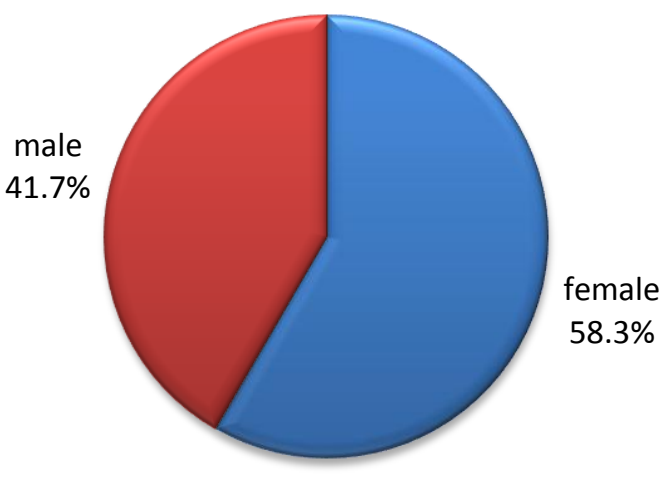

Figure 3 shows the proportion of age of smallholder sorghum farmers that were interviewed in the study area. The study revealed that $58.3 \%$ of the participants were females while $41.7 \%$ of the total respondents were males. The results indicate that the study area have more females farmers in the production of sorghum than their male counterparts. This result shows why females were remaining in rural areas to practice agriculture in order to look after their households in terms of food and tilling while males went to the urban areas for work in order to alleviate poverty. This reduces gender inequality in the village.

Figure 4: Farmers' household size

\section{Farmers' household size}

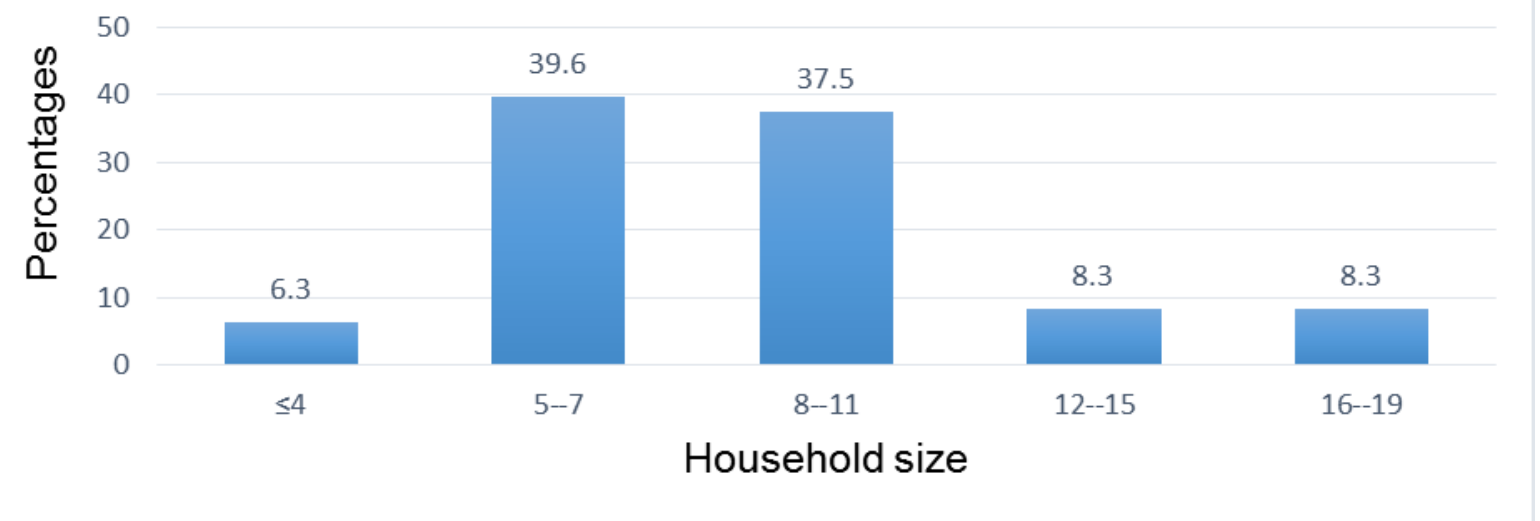

Figure 4, is all about the smallholder sorghum farmers and the size of their family in terms of number of people residing in their households. Household size has an influence on the volume of farming activities such that family labour can help improve production more than hired labourers. That is, if a household size is small 
the farmer will need to hire people to help in some farm activities such as weeding, fertilising, ploughing etc. The study revealed that $6.3 \%$ of the households interviewed had 4 members and less. $39.6 \%$ households had between 5 and 7 members. 37.5\% households had between 8 and 11 members. 8.3\% households had between 12 and 15 members and 8.3\% households had between 16 and 19 members.

Table 1: Cobb-Douglas results

\begin{tabular}{|c|c|c|c|c|}
\hline Independent variables & Coefficients & $\begin{array}{l}\text { Standard } \\
\text { error }\end{array}$ & t-ratio & $\begin{array}{l}\text { Significance } \\
\text { level }\end{array}$ \\
\hline Constant & 4.369 & 0.605 & 7.221 & 0.000 \\
\hline $\begin{array}{l}\text { Land size in ha } \\
\text { Supply of labour }\end{array}$ & $\begin{array}{l}0.803 \\
0.003\end{array}$ & $\begin{array}{l}0.105 \\
0.058\end{array}$ & $\begin{array}{l}7.648 \\
0.052\end{array}$ & $\begin{array}{l}0.000 \\
0.954\end{array}$ \\
\hline Access to irrigation water & 0.017 & 0.044 & 0.386 & 0.693 \\
\hline $\begin{array}{l}\text { Access to fertiliser } \\
\text { Seeds used }\end{array}$ & $\begin{array}{l}0.067 \\
0.542\end{array}$ & $\begin{array}{l}0.046 \\
0.176\end{array}$ & $\begin{array}{l}1.457 \\
3.080\end{array}$ & $\begin{array}{l}0.159 \\
0.004\end{array}$ \\
\hline $\begin{array}{l}\text { Farming experience of the } \\
\text { farmer }\end{array}$ & 0.069 & 0.049 & 1.408 & 0.169 \\
\hline Age of the farmer & -0.237 & 0.197 & -1.203 & 0.238 \\
\hline Gender of the farmer & -0.013 & 0.051 & -0.255 & 0.800 \\
\hline $\begin{array}{l}\text { Educational level of the } \\
\text { farmer }\end{array}$ & 0.001 & 0.020 & 0.046 & 0.989 \\
\hline Tractor use & 0.002 & 0.057 & 0.035 & 0.967 \\
\hline $\begin{array}{l}\text { Access to extension } \\
\text { services }\end{array}$ & 0.027 & 0.041 & 0.659 & 0.518 \\
\hline Credit access & 0.031 & 0.051 & 0.608 & 0.539 \\
\hline Farmers' household size & 0.032 & 0.079 & 0.405 & 0.691 \\
\hline
\end{tabular}

Technical efficiency and its determinants among smallholder sorghum farmers:Table 1 shows the Cobb-Douglas model that was used in defining technical efficiency of the farmers. The linear regression results show that two variables were important out of thirteen variables in table 1 above. The size of land and quantity of seeds used are the variables that were found to be significant. All the coefficients of the model have positive signs but age and gender of the farmers have negative signs.

Size of the land: Size of the land has a positive coefficient of 0.803 . This shows that $1 \%$ increase in the size of land would results in $80.3 \%$ increase in sorghum production. It was found significant at $1 \%$ significant level and a significant value of 0.000 . The results reveal that the size of the land is the most important resource in the production of sorghum and it implies that as the size of the land increases sorghum production will increase. This concurs with the results of Mustapha and Salihu (2015) on determinants of technical efficiency of maize/cowpea intercropping among women farmers in Gombe State, Nigeria.

Quantity of seeds used: Quantity of seeds used has a positive coefficient of 0.542 , meaning that $1 \%$ increase in quantity of seeds would results in $54.2 \%$ increase in sorghum production. Therefore, quantity of seeds produced is at $1 \%$ level significant and at a value of 0.004 . The results concur with Ataboh et al. (2014) on determinants of technical efficiency among rice farmers in Kogi State, Nigeria. Application of more seeds may increase output.

Table 2: Elasticity of factor inputs

\begin{tabular}{ll}
\hline Independent variables & Elasticity \\
\hline Size of land & 0.803 \\
Quantity of seeds used & 0.542 \\
Total (Returns to scale) & 1.345 \\
\hline
\end{tabular}

Table 2 depicts the elasticity of factor inputs. The return to scale was found by adding the value of betas ( $\beta$ ); it indicates what would happen to output of sorghum if factor inputs were to increase simultaneously. The 
elasticity of factor inputs is indicated in table 2 above. The results show that the return to scale of smallholder sorghum farmers in the study area is 1.345 which implies an increasing return to scale and thus, the output is increasing more than proportionally. An increasing return to scale indicates that farmers are technically efficient in the production of sorghum.

Table 3: Adjusted R square and standard error of estimates

\begin{tabular}{ll}
\hline Adjusted R square & Standard error of estimates \\
\hline 0.916 & 0.129 \\
\hline
\end{tabular}

Table 3 indicates the adjusted R square of 0.916 which indicates that $91.6 \%$ is explained by the independent variables in the model and the remaining $8.4 \%$ is from outside the model. The standard error of estimates in the table above, measures the accuracy of the model which implies that there are $12.9 \%$ chances of errors in the model. Therefore, it implies that the model was good and the variables included were relevant.The value of adjusted R squared and standard error of estimates show that the model is robust/good because $91.6 \%$ of the variables explained technical efficiency of smallholder sorghum farmers in the study area while $12.9 \%$ are the probabilities of making wrong estimates.

Challenges faced by smallholder sorghum farmers in Ga-Masemola village: Incident of pests, inadequate rainfall (lack of water), climate change, lack of capital, diseases and distance to the farm are some of the challenges identified in this study area. If these challenges are resolved, there will be an increased production of sorghum which will enhance the technical efficiency of sorghum farming. The main challenge facing smallholder sorghum farmers in the village is lack of water and most farmers depend mainly on rainfall for irrigation purposes. Lack or access to capital is also a major challenge faced by these farmers. It makes farmers unable to purchase adequate amount of seeds, fertilisers, pesticides etc.

Table 4: Challenges faced by smallholder sorghum farmers in Ga-Masemola

\begin{tabular}{lll}
\hline Challenges faced by farmers & Frequency & Percentages \\
\hline Diseases & 4 & 8.3 \\
Low capital & 10 & 20.8 \\
Pests & 7 & 14.6 \\
Distance to the farm & 2 & 4.2 \\
Lack of water & 21 & 43.8 \\
Climate changes & 4 & 8.3 \\
Total & 48 & 100 \\
\hline
\end{tabular}

Table 4, shows the array of challenges being faced by the sorghum farmers in the study area. $43.8 \%$ of the farmers complained of water for irrigation purposes. $20.8 \%$ of farmers have no capital to purchase some of the farming inputs. $14.6 \%$ of farmers interviewed are affected by pests. $8.3 \%$ of farmers are affected by crop diseases. $8.3 \%$ of farmers are affected by impact of climate change and while $4.2 \%$ indicated that distance to the farm is a challenge to them.

\section{Conclusion}

Inquiries on thesocio-economic characteristicsof smallholder sorghum farmers in Ga-Masemola village were inquired. The determinants of technical efficiency of smallholder sorghum farmers in Ga-Masemola village were additionally investigated. Finally, the difficulties confronted by smallholder sorghum farmers inGaMasemolavillage were featured.The outcome of this study reveals that the socioeconomic characteristics of smallholder sorghum farmers inGa-Masemola village include:farmingexperience, age, sexual orientation, educational level and family unit measure. The determinants of technical efficiency in Ga-Masemola village include: the measure of land and the quantity of seeds utilized, these factors were observed to be noteworthy. The difficulties confronted byfarmersinclude: infections, low capital, pests, distance to the farm; absence of water and weather instability. 


\section{Recommendations}

- Smallholder sorghum farmers in Ga-Masemola village should be giving an opportunity to acquire more arable land, with a specific end goal of increasing their production and their technical efficiency.

- A quality and enhancedextension services delivery systemmust be set up by government, and again, all the farming inputs like quality seeds shouldbe made accessible at affordableprices.

- The smallholder sorghum farmers should to be encouraged to utilize better and quality varieties of seeds with a specific end goal to enhance their technical efficiency.

- The smallholder sorghumfarmers require extension officers for training and dissemination of information about inputs allocation especially seeds. This may bring about an increase in sorghum output.

- Finally, the youth should to be encouraged to practice sorghum farming in light of the fact that they are young andstrong to perform the farm activities, they are also able to adapt to new and advanced technologies.

\section{References}

Adama, I. J. (2014). Analysis of the determinants of technical efficiency among some selected small scale farmers in Kogi State. International Journal of African and Asian Studies, 5, 24-30.

Ataboh, O. E., Umeh, J. C. \& Tsue, P. T. (2014). Determinants of Technical Efficiency among Rice Farmers in Kogi State, Nigeria. Journal of Agriculture and Sustainability, 6(1), 39-49.

Bahta, S., Baker, D., Malope, P. \& Katjiuongua, H. (2015). A meta-frontier analysis of determinants of technical efficiency in beef farm types: an application to Botswana. Botswana: International Livestock Research Institute: Gaborone.

Chepng'etich, E., Nyamwaro, S. O., Bett, E. K. \& KIzito, K. (2015). Factors that influence technical efficiency of sorghum production: a case of small holder sorghum producers in Lower Eastern Kenya. Advances in Agriculture. From: http://dx.doi.org/10.1155/2015/861919 (Received on 17 March, 2017).

Fadzim, W. R., Aziza, M. I. A., Mata, S. H. C. \& Maamora, S. (2016). Determinants of technical efficiency among smallholder cocoa farmers in Malaysia. The European Proceedings of Social and Behavioural Sciences.

Koirala, K. H., Mishra, A. K. \& Mohanty, S. (2013). Determinants of rice productivity and technical efficiency in the Philippines. Department of Agricultural Economics and Agribusiness, Louisiana State University, Baton Rouge.

Lefophane, M. H., Belete, A. \& Jacobs, I. (2013). Technical efficiency in input use by credit and non-credit user emerging farmers in Maruleng Municipality of Limpopo Province, South Africa. African Journal of Agricultural Research, 8(17), 1719-1724.

Mmbengeni, M. E. \& Mokoka, M. S. (2002). Provincial report on education and training for agriculture and rural development in Limpopo Province. From: http://www.nda.agric.za/docs/et/Limpopo.pdf (Retrieved on 1 August, 2017).

Mokgalabone, M. S. (2015). Analysing the technical and allocative efficiency of small-scale maize farmers in Tzaneen municipality of Mopani district: a Cobb Douglas and logistic regression approach. Master Dissertation, Unpublished. Limpopo: University of Limpopo.

Mustapha, A. \& Salihu, A. (2015). Determinants of technical efficiency of maize/cowpea intercropping among women farmers in Gombe State, Nigeria. Journal of Agriculture and Sustainability, 7(2), 245-258.

Njeru, J. (2010). Factors influencing technical efficiencies among selected wheat farmers in Uasin Gishu District, Kenya (No. RP_206). From: https://core.ac.uk/download/pdf/6476029.pdf (Retrieved on 1 August, 2017).

Otieno, D. J., Hubbard, L. \& Ruto, E. (2012). Determinants of technical efficiency in beef cattle production in Kenya. International Association ofAgricultural Economists (IAAE) Triennial Conference, Foz do Iguacu, Brazil, 18-24. 